\title{
KOOPERÁCIÓ A TÖRTÉNETTUDOMÁNY ÉS KÖZOKTATÁS KÖZÖTT
}

\author{
DÉVÉNYI ANNA * - GŐZSY ZOLTÁN ** \\ * a Pécsi Tudományegyetem Bölcsészettudományi Karának \\ adjunktusa \\ devenyi.anna@pte.hu \\ ** a Pécsi Tudományegyetem Bölcsészettudományi Karának \\ egyetemi docense \\ gozsy.zoltan@pte.hu
}

Az alábbiakban ${ }^{1}$ két olyan kezdeményezést mutatunk be, melyek azt a célt tüzték ki, hogy a történettudomány és a történelemtanítás, a történészek és a történelemtanárok, illetve a felsőoktatás és a közoktatás közötti kapcsolatot és szakmai együttmüködést intenzívebbé tegyék. Az egyik egy - reményeink szerint hamarosan online folyóiratként is megjelenő - weboldal (Árkádia történelem szakmódszertani portál ${ }^{2}$, a másik egy középiskolai tanulmányi verseny (Kreatív történelem tanulmány verseny ${ }^{3}$ ). Mindkettő a Pécsi Tudományegyetem Bölcsészettudományi Kar, Történettudományi Intézete, valamint a PTE gyakorló gimnáziuma, a PTE Babits Mihály Gyakorló Gimnázium és Szakközépiskola együttműködésén alapszik.

A weboldal neve Árkádia ${ }^{4}$, ennek létrehozására a TÁMOP 4.1.2-08/1/B pályázat keretében nyílt lehetőség, mely a Bologna-rendszerü, új típusú tanárképzés támogatását célozta meg. A honlap az irodalom és a történelem tantárgyakhoz kapcsolódik, ezek közül itt a történelmi számokkal foglalkozunk részletesebben, de az alapkoncepció és a célkitüzés azonos az irodalmi rész esetében is. Az Árkádia weboldal megálmodója Pethöné Nagy Csilla középiskolai irodalomtanár, tankönyvszerző, szakmódszertanos. A szerkesztőbizottságban irodalmárok, történészek, szakmódszertanosok és középiskolai tanárok müködnek együtt, ez a közös munka kezdettől, tudatosan a tudomány és a közoktatás kooperációját kívánta erősíteni.

A weboldal létrehozását különösen indokolttá tette, hogy Magyarországon a tudomány és az oktatás, illetve a felsőfokú és a közoktatás között még mindig viszonylag nagy a távolság, és csekély az érdemi együttmüködés. A kutatók többsége nem rendelkezik valós ismeretekkel az oktatás igényeiröl, és csak kevesen érzik

\footnotetext{
${ }^{1}$ A tanulmány a TÁMOP-4.1.2B.2-13/1-2013-0014 projekt keretében készült.

${ }^{2}$ URL: www.arkadia.pte.hu Letöltés ideje: 2015. 10. 10.

${ }^{3}$ URL: www.kreativtortenelem.hu Letöltés ideje: 2015. 10. 10.

${ }^{4}$ URL: www.arkadia.pte.hu, valamint https://arkadiafolyoirat.wordpress.com Letöltés ideje: 2015. 10. 10 .
} 
fontosnak, hogy szakmai kapcsolatba kerüljenek általános vagy középiskolai tanárokkal, a tudományos kutatások eredményei pedig csak lassan szivárognak át az oktatásba és a tankönyvekbe.

\section{A történettudomány és történelemtanitás viszonyának alakulása}

Mielött bemutatnánk magát a versenyt és a weboldalt, a mögöttük húzódó koncepciót, illetve célokat, $\mathrm{s}$ az eddig elért eredményeket, érdemes röviden felvázolni, hogyan is alakult a magyarországi történelemtanítás története során a történelemkutatás és a történelemtanítás viszonya egészen napjainkig. Így jobban érthetővé válik, hogy miért állt elő a jelen helyzet, amiben e két terület egymástól távol került ugyan, de utakat keres a közeledésre. A két fél viszonyát, a kapcsolat intenzitását, a tankönyvszerzők, illetve a tanárok személyében véljük megragadhatónak.

A történelemtanítás professzionalizálódása, önálló tantárggyá válása Magyarországon a 18. századra tehető, a század második felére általánossá válik a középiskolákban. Ekkor jelennek meg az első tankönyvek, tankönyvnek tekinthetö összefoglalások is. Ezeket, többnyire német nyelvterületröl egyszerüen átvették, vagy ezen minták alapján írták meg a magyar iskolák számára.

Pray György (jezsuita szerzetes), a korszak legelismertebb magyar történésze készítette el az első államilag hivatalosan elismert és ajánlott történelem tankönyvet, mely 1802-ben jelent meg. Ám hiába írta elő tanügyi rendelet (a II. Ratio Educationis, 1806-ban) a használatát, mégsem terjedt el, mivel alapvető didaktikai elvárásoknak nem felelt meg, például rendkívül nagy volt a terjedelme. Azt a tankönyvet, amely Prayé helyett végül országszerte népszerü lett, egy középiskolában oktató tudós tanár, Spányik Glicér írta meg. A korszak másik sikeres tankönyvét Bolla Márton, a kolozsvári líceum történelemtanára és igazgatója jegyzi. Az 17881879-ben Kolozsváron megjelent tankönyv sikerének titka - szakmai minősége mellett - didaktikusságában és rövidségében rejlett. Bolla a bevezetésben egyértelművé teszi, hogy a taníthatóságot figyelembe véve tárgyalja és értékeli a történelmet: „A történet általában viselt dolgok' elbeszélése; ha tekintjük mint tudományt, nevezetes, bizonyos és meggondolva választott eseményeknek tanitásra alkalmazott elbeszélése. Alakja a' tanitáshoz illesztett elöadásmód, czélja a' tudomány, tárgya a' kiválasztott nevezetes és bizonyos események.” (Bolla, 1847, o.n.) A 19. század későbbi tankönyvszerzői is jellemzően olyan történettudósok voltak, akik maguk is tanították a tantárgyat középiskolákban (Budai Ézsaiás, Csengery József stb.) (Gözsy-Dévényi, 2011).

A történelemtanításban a 19. század végétől a történészi tudományosság mellett egyre fontosabb követelménnyé vált a pedagógiai felkészültség is. Jelentős változást hozott Magyarországon a tanárképzés egységesítése és 1870-től a tanárképző intézetek felállítása, valamint az első középiskolai törvény kiadása. Ezek a fejlemények nagyban hozzájárultak a tanári pálya professzionalizálódásához. Ezzel 
párhuzamosan jelent meg, illetve vált fokozatosan önálló tudományterületté a szakdidaktika.

Az 1920-as évek tankönyvszerzöi között egyrészt kíváló történelemtudósokat találunk, (például Domanovszky Sándor, Závodszky Levente), másrészt neves szakdidaktikusokat (például Ember István, Dékány István stb.). Az 1930-as évek kultúrpolitikáját meghatározó magyar kultuszminiszter, Hóman Bálint elképzelése az volt, hogy a tankönyveket szakdidaktikusoknak kell megírniuk, így az állami megrendelésre készült tankönyvek szerzöi között ebben a korszakban már alig találunk történészeket, viszont jeles történelemdidaktikusokat szép számban. Ugyanekkor a középiskolai tanárok köréből egyre kevesebben engedhették meg maguknak, hogy tudományos munkát is végezzenek. Ennek túlnyomórészt anyagi okai voltak. A gazdasági világválság, a hatalmas munkanélküliség az értelmiség körében a tanárok anyagi megbecsülésének csökkenését vonta maga után. Másrészt az 1930-as években megfigyelhető, hogy az állam egyre szigorúbban ellenőrizte a közoktatást, így a tanárok munkáját is, ami szintén nem kedvezett az alkotómunkának. A történelemtanítás az ország szellemi (és politikai-ideológiai) nevelése szempontjából létfontosságú terület volt, így különös figyelmet, viszont egyre kevesebb önállóságot kapott. Történelemtanítás és kutatás egyre markánsabban kezdett szétválni ebben a korszakban (Mészáros, 1989; Albert, 2006; Gözsy-Dévényi, 2011).

Az igazán mély szakadék a kommunista diktatúra idején, annak is inkább a második felében jött létre. A Rákosi-korszakban a történész szakma addig elismert nagyjait félreállították, új történészek kerültek az Akadémia élére és az egyetemi katedrákra. A magyar történelmet viharos gyorsasággal írták újjá a marxista történelemszemlélet szerint. A hivatalos történetírás és a történelemtanítás ebben a pillanatban tökéletes egységben volt, mindenhol a marxizmus uralkodott.

A helyzet a Kádár-korszak közepétől változott meg. A tudomány és a mủvészetek terén is megindult egyfajta liberalizáció, a párt kijelentette, hogy a tudományba nem kíván beleszólni, s nagyjából ehhez tartotta is magát. A történészek eltérhettek a marxista történelmi materializmus eszméjétöl, sőt a hetvenes évektől külföldi (nyugati) szakfolyóiratokat is be lehetett hozni az országba. A marxizmus kereteiből kilépö, modern, szakszerü kutatási eredményeket a szük körben terjesztett szakmai lapokban publikálni is lehetett (Romsics, 2011). A szélesebb körben terjesztett tudományos ismeretterjesztő kiadványokat azonban továbbra is szigorúbban cenzúrázták és az új eredmények a tankönyvekbe sem kerülhettek bele. Bár ezekből is eltünt a vulgármarxizmus, de az osztályharcon alapuló materialista történelemszemlélet kötelező maradt (Szöke, 2004). Ekkor vált szét legjobban a történetírás és a történelemtanítás Magyarországon.

A rendszerváltás után ezek az eszmék - mégha észrevétlenül, indirekt módon is - de szívósan tovább élnek. A tankönyvekböl ugyan azonnal elkezdték kigyomlálni a durva marxista-leninista toposzokat, de ez lassú folyamat. A kutatások folyamatosan hoznak újabb és újabb eredményeket, melyek csak rendkívül lassan ke- 
rülnek át az oktatási rendszerbe. A tankönyvkiadás és engedélyeztetés lassú és bonyolult, s ennél is tovább tart, míg a tanárok maguk is elfogadják, megismerik az új eredményeket és elkezdik használni azokat a tanteremben. Ennek oka többek között a pedagógusok túlterheltsége és alulmotiváltsága, valamint az is, hogy a továbbképzéseken jellemzően inkább módszertani vagy informatikai ismereteiket bővíthetik, a történettudomány legújabb eredményeit bemutató szakmai továbbképzésekből egyszerüen nagyon kicsi a kínálat. Ez amiatt is lehet, mert - talán épp a fentiek miatt - lassanként kialakult az a helyzet, hogy a magyar tudósok (tisztelet a kivételnek) nem becsülik túl sokra a közoktatást, a tankönyveket és a pedagógusokat.

Az utóbbi években - különösen, amióta csökkenést mutat a történelem szak iránti érdeklődés, és éles versenyhelyzet alakult ki a felsőoktatási intézmények között a fennmaradásukért - valamelyest kezd megváltozni ez a helyzet és a történészek is kezdik felismerni, hogy itt kölcsönös függőségi helyzetről van szó. A felsőoktatási reformok, a tanárképző egyetemek és föiskolák magas száma és a csökkenő hallgatói létszám, valamint a fejkvóta-rendszer a tanárképzésre általában rossz hatással van. Van azonban egy olyan pozitív „mellékterméke” is ennek a depresszív helyzetnek, hogy a diákokért folyó versenyben az egyetemek, egyetemi oktatók és kutatók kezdenek nyitni a közoktatás felé, a közoktatás igényei felé. A Bologna (és az újabb osztatlan tanári) rendszerekben teljesen szétvált a történész és a történelemtanár képzés és a remélt munkaerö-piaci előnyök, lehetőségek miatt a hallgatók túlnyomó többsége a tanárszakot választja. Ezek a hallgatók azt várják el a képzöhelyektől, hogy a pedagóguspályára készítsék fel őket, gyakorlati tanári tevékenységük során használható tudást, ismereteket és képességeket szerezzenek. Ha az egyetemek meg akarják tartani diákjaikat, ki kell elégíteniük ezeket az igényeket.

Napjainkban ennek is köszönhetően egyre nagyobb szándék figyelhető meg a tudomány és a közoktatás, a tudósok és a pedagógusok közötti kapcsolat helyreállítására. Ezek közül mutatunk be tehát két pécsi kezdeményezést.

\section{Az Árkádia szakmódszertani portál}

Az Árkádia weboldal a Pécsi Tudományegyetem Babits Mihály Gyakorló Gimnáziuma és a Pécsi Tudományegyetem Bölcsészettudományi Kara, ezen belül is a Történettudományi Intézet és az Irodalomtudományi Tanszék összefogásával valósult meg. ${ }^{5}$ Ennek köszönhetően a tudomány művelöi, a tanárképzésben részt vevő oktatók és hallgatók, valamint a gyakorló pedagógusok egyaránt megjelennek szerzőként, szerkesztőként és felhasználóként a honlapon. Az oldal szerkezete és tartalma alapvetően e szereplők közötti együttmüködésen alapul, ezt kívánja - kicsit sarkí-

\footnotetext{
${ }^{5}$ Az Árkádia történelem szakmódszertani portál szerkesztőbizottsága: Dr. Gözsy Zoltán (egyetemi docens, PTE Történettudományi Intézet), Priskinné Rizner Erika (szakvezető történelemtanár, PTE Babits Mihály Gyakorló Gimnázium és Szakközépiskola), Dévényi Anna (adjunktus, PTE Történettudományi Intézet).
} 
tottan fogalmazva - kikényszeríteni. Az Árkádia weboldal tematikus számokkal jelenik meg. A számok témája az érettségi követelményekhez és a gyakorló pedagógusok igényeihez igazodik. Az eddig megjelent számok közül néhány:

- a nemzetiségi kérdés,

- a 18-19. század politikai eszméi,

- az ókor története,

- az ipari forradalom kora,

- a barokk és a reformáció.

A számok tehát vagy egy speciális téma, vagy egy korszak köré szerveződnek. Egy-egy számon belül jellemzően öt kisebb „tananyag-csomag” található, öt kisebb témával. Egy ilyen „csomag” három részből áll: tanulmányból, forrásokból és óravagy modultervböl.

A tanulmány maximum fél ív terjedelmü és közérthető nyelvezetet használ, szerzője a téma egy neves szakértője. A tárgy problémaközpontú bemutatása mellett a szerző reflektál arra is, hogy mindez hogyan jelenik meg a ma használatos történelemtankönyvekben, az oktatásban. Ha úgy látja, hogy ezek torzításokat vagy aránytalanságokat, esetleg helytelen adatokat közvetítenek, akkor erre felhívja a figyelmet. A tanulmányhoz természetesen ajánlott irodalom is kapcsolódik, lehetőleg külön a pedagógusoknak és külön a diákoknak.

A történelemtanítás a hatályos oktatási dokumentumokban rögzített kompetenciaalapú tanítás elvárásait a forrásközpontúság által (is) tudja teljesíteni. A forrásközpontú történelemtanítás mára alapvető követelménnyé vált és széles körben elterjedt, ami elsősorban annak köszönhető, hogy a 2005-ben megreformált történelem érettségi erre épül (F. Dárdai-Kaposi, 2006). Éppen ezért az Árkádiában megjelenő tanulmányok szerzői témájuk kapcsán a közoktatásban felhasználható forrásokat, forrásrészleteket is közreadnak. Ez tehát a tananyag-csomag második eleme.

A harmadik elem az első kettőre építve, illetve azokat felhasználva készül. A téma tanórai felhasználására mutat példát, egy konkrét óravázlat vagy modulterv formájában ad ötleteket. Ezeket az anyagokat gyakorló pedagógusok készítik, akik ügyelnek arra, hogy a legújabb pedagógiai és módszertani eredményeket alkalmazzák. Fontos cél, hogy a tanulmány és az óravázlat szerzője között személyes kapcsolat jöjjön létre, egymás munkáját kölcsönösen segítsék és véleményezzék, ha kell, korrigálják. A szerkesztők törekednek rá, hogy a tudomány és az oktatás képviselői ugyanazon téma apropóján kapcsolják össze tudásukat. Ahol sikerült létrehozni e kapcsolatot, ott gyümölcsöző együttmüködések alakultak ki.

Az eddigi tapasztalatok szerint a tanárok nagyon élvezték, hogy végre szakmai kérdésekről beszélhetnek történészekkel, a történészek pedig mélyen megdöbbentek, amikor látták, hogy mennyi munkát, szakértelmet és kreativitást igényel a tanulási-tanítási folyamat megtervezése. Több történész számolt be arról, hogy mindeddig azt hitte, a tanárok munkája a tankönyvek ismételgetéséből áll, mint ré- 
gen, amikor ők voltak iskolások. A tanárokról és a közoktatásról alkotott véleményük megváltozott e szakmai találkozás hatására. Arra is láthattunk példát, hogy egyes történészek nyomon követték a tanulmányuk alapján készült óratervek tanórai megvalósulását és elmentek hospitálni a középiskolákba. Megfigyelhető az is, hogy a projektben részt vevő történészek, akik a történelem tanárképzésben is oktatnak, megváltoztatták kurzusaik tematikáit és elkezdték azokat a közoktatás tartalmi és módszertani igényeihez igazítani.

Az Árkádia portál üzemeltetésének anyagi hátterét a fent nevezett TÁMOP pályázat 2010-től két éven át biztosította, azóta a számok megjelenése esetlegessé vált, de minden évben publikálásra kerül egy-egy szám a 2012/2013-as tanévben elindított Kreatív Történelem tanulmányi versenyhez kapcsolódóan, a verseny aktuális tematikájához igazodva.

\section{A Kreativ történelem tanulmányi verseny}

Az elsősorban középiskolásoknak szóló versenyt szintén a PTE Babits Mihály Gyakorló Gimnáziuma és a PTE BTK Történettudományi Intézete hívta életre, több célból. ${ }^{6}$ Egyik legfontosabb ezek közül, ebben az esetben is, a felsőoktatás és a közoktatás közötti kapcsolat erösítése volt. A felkészülést segítő szakirodalmak (köztük az Árkádia számai) a legfrissebb kutatási eredményekre és történelemszemléletre épülnek, a feladatok maguk - hasonlóan az Árkádia óraterveihez - a szakmódszertani megújulást támogatják. A szervezésben középiskolai és egyetemi oktatók közösen vesznek részt, hogy a középiskolai történelemtanítás, illetve a diákok igényeihez igazodó és tudományosan is megalapozott, minőségi versenyprogramot tudjanak létrehozni. A történettudományos szempontok és kritériumok mellett még nagyobb hangsúlyt fektetnek a szakmódszertani igényességre.

A verseny nemcsak a közoktatás és a tudomány világa, hanem a közoktatás és a tanárképzés közötti együttmüködést is serkenteni kívánja. A feladatlapok összeállításában, lektorálásában és javításában részt vesznek doktoranduszok és a pécsi történelem tanárképzés hallgatói is. A hallgatók bevonása különösen fontos szempont, hiszen ezáltal szakmai gyakorlatot szerezhetnek, s felkészülhetnek a tehetséggondozás egyes feladatainak ellátására.

Fontos emellett az is, hogy a diákok az érdekes és kreativitásukra építő feladatok megoldásával élővé tegyék az iskolai keretek között megismert történelem tananyagot. A versenyfeladatok megoldásához önálló ismeretszerzésre, a megfelelö szakirodalmak felkutatására, információgyüjtésre, szelektálásra és rendszerezésre,

\footnotetext{
${ }^{6}$ A Kreatív történelem tanulmányi verseny szervezői: Priskinné Rizner Erika (szakvezető történelemtanár, PTE Babits Mihály Gyakorló Gimnázium és Szakközépiskola), Dr. Nagy Mariann (egyetemi docens, PTE Történettudományi Intézet), Dévényi Anna (adjunktus, PTE Történettudományi Intézet), Dr. Gözsy Zoltán (egyetemi docens, PTE Történettudományi Intézet) Szlanyinka Éva, Pásztory Levente, Boros Gábor (doktoranduszok, PTE BTK Történettudományi Doktori Program).
} 
az áttekintett források szintetizálására és az ismeretek gyakorlati alkalmazására van szükség. Mindeközben a diákok nemcsak különböző típusú forrásokkal és szakirodalommal, de közgyüjteményekkel is megismerkedhetnek. A Kreatív történelem tanulmányi verseny minden évben egy, a történelem érettségin jellemzően előforduló, hangsúlyos téma feldolgozását tüzi ki célul. A felkészülés során a vetélkedő résztvevői nem csupán intenzívebb és komplexebb tudást szereznek a témakörrel kapcsolatban, de a feladatok elkészítése révén a múlthoz füződő viszonyuk is személyesebbé válik. Nem titkolt cél az sem, hogy a verseny kedvet ébresszen a felsöfokú történelmi tanulmányok folytatására.

A kreatív történelem tanulmányi vetélkedő csapatverseny (négyfös csapatok jelentkezhetnek), vagyis egyben az együttmüködés terepe is. A vetélkedő három fordulóból áll. Az első két forduló feladatai a verseny honlapján kerülnek közzétételre (szeptemberben és decemberben), ezek megoldására két-három hónap áll a csapatok rendelkezésére, az eredményeket pedig postán (elektronikus vagy hagyományos úton) kell beküldeniük. ${ }^{7}$ A feladatlapok jellemzően két komplex feladatot tartalmaznak. Ezekhez minden esetben tartozik a megoldást segítő ajánlott szakirodalom, valamint értékelési szempontok és a megszerezhető pontok száma is, az egyes szempontok szerint. A feladatokra 0-100 pontot lehet kapni, ebből a kreativitás és a kivitelezés módja általában 20-30 pontot, a felhasznált irodalmak minősége, mennyisége és relevanciája 10-20 pontot, a megoldás szakmai tartalmai 50-70 pontot tesznek ki.

Az első forduló feladatai között mindig szerepel egy olyan, amely a téma, a korszak egészének vázlatos áttekintésére, a legfontosabb tények és összefüggések felfedezésére sarkall, ez jellemzően egy folyamatábra készítése, melyhez változatos müfajú mellékletek tartoznak.

Az 2014/2015-ös versenykiírásban, melynek témája a hidegháború, ez például így fest:

\section{I. feladat}

a) Készítsetek folyamatábrát a klasszikus hidegháború eseményeiről! Az ábrában csak az általatok legfontosabbnak ítélt eseményeket tüntessétek fel, az elemek száma ne haladja meg a 20-at. Kiindulópontnak használjátok Fischer Ferenc: A kétpólusú világ címủ munkáját, illetve annak I. és III. ábráját (Fischer Ferenc: A kétpólusú világ 1945-1989. Dialóg Campus Kiadó, Budapest-Pécs, 2005. I. és III. tábla)! A folyamatábrát rajzolhatjátok kézzel, szerkeszthetitek bármilyen szoftver segítségével (photoshop, ppt, prezi stb.), lehet statikus vagy akár interaktív. Legyetek kreatívak!

\footnotetext{
${ }^{7}$ URL: www.kreativtortenelem.hu, valamint www.facebook.com/kreativtortenelem Letöltés ideje: 2015. 10. 10 .
} 
b) A folyamatábrából válasszatok ki egy eseményt és mutassátok be úgy, mintha egy hírszerző jelentene róla. Hogy melyik állam hírszerzője, az rajtatok áll! A jelentés kb. 1 gépelt oldal terjedelmü legyen. A feladatmegoldáshoz csatoljátok a felhasznált irodalmak listáját (ügyeljetek a bibliográfiai adatok pontos megadására: szerző, cím, kiadó, kiadás helye, éve, oldalszám)!

Az első forduló másik feladata, típusát tekintve próbál minél nagyobb teret hagyni a diákok kreativitásának, témájában pedig jellemzően egy olyan részletre fókuszál, mely a diákokat különösen érdekelheti, tehát ami alkalmas az érdeklődés felkeltésére. Példaként álljon itt a 2013/2014-es feladat. Ebben az évben az első világháború volt a téma.

\section{II. feladat}

a) Ebben a feladatban egy, a hátországban élő nő háborús hétköznapjait kell bemutatnotok. A helyszín Magyarország.

Írjatok egy fiktív visszaemlékezést egy nő nevében, amelyben a háború éveire tekint vissza! A szöveg ugyan fiktív, de törekednetek kell a történeti hüségre, (olyan históriát írjatok le, ami valóban akár meg is történhetett volna)! A korszak alaposabb megismeréséhez használhatjátok az általunk ajánlott irodalmat, de kereshettek más szakmunkákat is. Fontos, hogy a felhasznált szakirodalmakat mindenképpen tüntessétek fel!

A visszaemlékezésben térjetek ki az alábbi szempontokra:

Derüljön ki a visszaemlékező hölgyről...

- ... lakóhelye, környezete (város, falu...), társadalmi helyzete, családi körülményei, esetleg mindezek változásai.

- ... életmódja és az abban bekövetkezett változások (munka, öltözködés, étkezés, szabadidő stb.).

- ... hogy hogyan tartotta a kapcsolatot a fronton lévő hozzátartozóival, milyen információi voltak a fronton történő eseményekröl.

- ... hogy milyen volt az ő és a környezetében élők hangulata, hogyan változott ez a háború során.

A visszaemlékezés terjedelme ne haladja meg a 4 gépelt oldalt (8-10 ezer leütés szóközökkel). A beadandó dokumentumot szerkeszthetitek számítógépen, de készíthetitek kézzel is!

Mielőtt nekiálltok a munkának, érdemes a visszaemlékezés (memoár) müfaji sajátosságaival is megismerkednetek, ehhez segítséget találtok az ajánlott irodalomban. 
b) A visszaemlékezéshez illesszetek mellékleteket is, amelyek hitelesen dokumentálják, alátámasztják a visszaemlékezésben leírt, bemutatott eseményeket, állapotokat. Mind a négy szemponthoz kapcsolódjon 2-2 forrás (összesen tehát $8 \mathrm{db}$ ).

Ezek a mellékletek ne fiktívek legyenek, mint a visszaemlékezés szövege, hanem kutassatok fel eredeti történeti forrásokat (levelek, levelezőlapok, újságcikkek, fényképek, hivatalos okiratok, hadijelentések, rendeletek, naplórészletek stb.) az első világháború éveiből és azokat illesszétek hozzá a kitalált történethez (vagy fordítva is dolgozhattok: az összegyüjtött forrásokhoz találjátok ki a hozzá illö történetet).

Fontos, hogy a mellékletben csatolt források valóban kapcsolódjanak a visszaemlékezés szövegéhez, hogy érdemi információkat hordozzanak, a téma szempontjából relevánsak legyenek, változatos típusúak és témájúak legyenek, és hogy pontosan jelöljétek meg a források lelőhelyét.

Az első világháború éveiről rengeteg forrás jelent meg különféle forráskiadványokban, illetve sokat találhattok az interneten is. Néhány ötletet adunk az ajánlott irodalmak között, de bátran kereshettek másokat is, sőt akár levéltárakban vagy a családi ereklyék között is kutathattok!

A második fordulóba a 80 százalék felett teljesítő csapatok jutnak tovább. Ennek feladatai az aktuális versenytéma egy-egy jellemző, de a közoktatásban kevésbé hangsúlyos szegmensét ragadják meg, az eddigiekhez hasonlóan komplex feladatok segítségével. Fontos szempont, hogy a feladatlapon valamilyen módon helyet kapjanak térképes feladatok is. A verseny szervezői ügyelnek arra is, hogy a feladatok között minden esetben legyen olyan, amely a hétköznapi élet kérdéseivel foglalkozik, ami a korszakot ,alulnézetböl” láttatja, ily módon különösen alkalmas arra, hogy a korszakot ne csak megismerjék, de meg is értsék a diákok, s akár személyes kötődésük is kialakuljon. Minden feladat esetében fontos, hogy a megoldáshoz a tanulók kreativitására is szükség legyen.

Példaként a második forduló feladataira a 2012/2013-as feladatlapot közöljük, melyben szintén érvényesültek a fent bemutatott szempontok. 


\section{3/2014. « Fából vasparipa » az ipari forradalom kora. A második forduló feladatai:}

A feladatlap az ipari forradalom következményeivel foglalkozik egy elképzelt, idealizált magyarországi város példáján keresztül. Elsőként e város infrastrukturális fejlődését kell bemutatni, illetve e város társadalmának változásait, a második feladat a városban lakók életmódját (lakáskörülményeit vagy szabadidős tevékenységét vagy társadalmi életét) vizsgálja az 1910-es években.

\section{I. feladat}

Mutassátok be egy elképzelt magyarországi város infrastrukturális fejlődését az 1840-es és az 1910-es évek között! (A város méreteiről, társadalmáról a feladat I./3. pontja is ad információkat, ezeket is vegyétek figyelembe.)

A mellékletben egy várostérképet találtok, ami egy fiktív magyarországi várost ábrázol az 1840-es években. Az utcaszerkezet mellett jelöltük a fontosabb középületeket, közintézményeket, a közlekedési hálózatot. Nem a teljesség igényével, csak jelzésszerüen feltüntettünk néhány ipari és kereskedelemi létesítményt (mühelyt, üzletet) is. (Jelmagyarázatot szintén a mellékletben találtok.)

Feladatotok az, hogy ebből kiindulva bemutassátok e város fejlődését az alábbi módon:

I/1. Találjatok ki nevet a városnak!

I/2. Rajzoljátok meg (a mintához hasonló módon) a város 1910-es térképét! A térképen (a cím, a tájolás és a jelmagyarázat mellett) jelöljétek

- az utcahálózatot,

- a fontosabb középületeket, közintézményeket,

- a fontosabb ipari/kereskedelmi létesítményeket,

- a közmüveket,

- a közlekedési hálózatot!

I/3. A térképhez a változásokat, illetve azok okait és irányát leíró szöveges magyarázatot is mellékeljetek, max. 2 gépelt oldal terjedelemben! A szövegben térjetek ki a következőkre:

- Hogyan és miért változott meg a város szerkezete (pl. hol, miért, hogyan jöttek létre új városrészek)?

- Milyen új közlekedési eszközök jelentek meg?

- Hogyan fejlödött a város ipara és kereskedelme?

- Milyen új közintézmények jöttek létre?

- Hogyan változott a város lakosságának száma? (Kiinduló adatnak használjátok a következőt: 1840-ben a lakosok száma: 6000 fö).

- Hogyan és miért változott a város nemzetiségi megoszlása? Kiinduló adatnak használjátok a következőt: 1840-ben a nemzetiségi megosz- 
lás: 2823 (47,05\%) szlovák, 1284 (31,55\%) német, 1284 (21,40\%) magyar nyelvü lakos.

Készítsetek a szöveghez magyarázó ábrákat (diagram, táblázat) is!

I/4. A feladat mellé csatoljátok a megoldáshoz felhasznált irodalmak, illetve források jegyzékét!

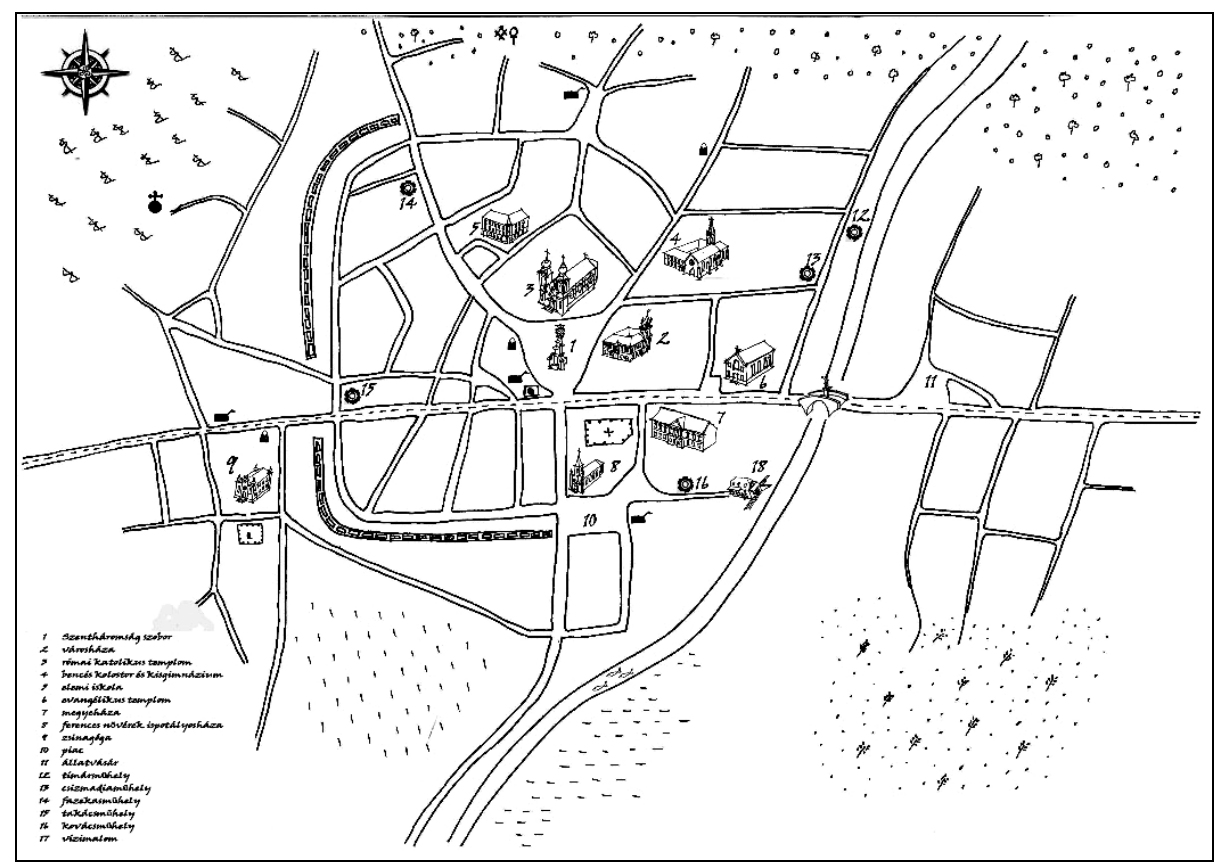

1. ábra: Az 1. feladathoz megadott alaptérkép

\section{II. feladat}

Mutassátok be az elképzelt város lakóinak hétköznapjait, életmódját az 1910-es években! A feladatmegoldás előtt válasszátok ki a megoldásotok múfaját és témáját is! Három téma közül választhattok:

1. társadalmi szervezetek, egyesületi élet, vagy

2. lakáskultúra, vagy

3. szabadidő, szórakozás.

A három téma egyikéről az alábbi három müfaj valamelyikében kell írnotok:

1. Naplórészlet: a város egy, tetszőleges életkorú, foglalkozású, nemü stb. lakójának 1910 körül vezetett naplójából közölt részletek. 
vagy

2. Blog: hasonlóan a naplórészlethez, itt is az 1910-es években keletkezett blogot kell létrehozni (feltételezve, hogy ez lehetséges volt), a bejegyzések stílusa tartalma ennek megfelelően legyen korhü, de használjátok ki a blog nyújtotta multimédiás lehetőségeket is (ha találtok korabeli képeket, hangfelvételeket stb., linkeljétek be őket, a bloglayoutját tervezzétek a századelő hangulatának megfelelően)! A blogot bármely portálon (blogspot, blogger, wordpress stb.) létrehozhatjátok, a kitöltött feladatlapban csak a linket kell megadnotok.

vagy

3. Újságcikk: a városban az 1910-es évek körül megjelenő újságban (napilap vagy tetszőleges folyóirat, magazin stb.) megjelenő cikk, pl. tudósítás valamely eseményröl, riport, interjú...

Az írás terjedelme a naplórészlet és az újságcikk esetén: 5-6 ezer karakter (szóközökkel). Az írás terjedelme blog esetén: 3-4 ezer karakter (szóközökkel).

A feladat megoldását segítő szempontok, témánként:

Társadalmi szervezetek, egyesületi élet:

- a szervezet, egyesület jellege (országos vagy helyi; egyházi, állami; jogi formája, neve)

- a szervezet, egyesület tevékenysége, céljai (milyen jellegü, pl. jótékonysági, tudományos, szakmai, nyelvmüvelő, irodalmi, vallási, művészeti, gazdasági, sport, szórakozási célú; milyen rendszerességű a tevékenység, miben nyilvánul meg a tevékenység)

- a szervezet, egyesület tagsága (a tagság száma, gyarapodása vagy csökkenése; a tagság etnikai, vallási, nemi összetétele; társadalmi összetétele: diákság, polgárság, arisztokraták, munkásság; önkéntes, meghívásos, jelöléses tagság)

- a település mérete, lakossága, ahol a szervezet müködik; a szervezet hatóköre

- a szervezet, egyesület alkalmai, ünnepei, évfordulói, gyülései (heti, havi, éves rendszerességü ülések; ünnepek, jubileumok, évfordulók, országosvagy világtalálkozók)

- a szervezet, egyesület müködésének külsőségei (öltözködés, egyenruha; használt helységek, épületek, állandó vagy változó hely)

Lakáskultúra:

- a ház mérete (földszintes vagy emeletes; többlakásos vagy nem) és elhelyezkedése (város központjában vagy külvárosban), milyen építőanyagokból épült (tégla cserépfedéssel, vályog nád/zsúptetővel, faház zsindellyel) 
- a lakás bérlemény vagy saját tulajdon?

- a lakás mérete (szobák száma, funkciója; kiszolgáló helyiségek: konyha, kamra, előszoba)

- a lakás komfortfoka (fütés, vízellátás/fürdőszoba, WC, világítás)

- a szolgálók világa (cselédszoba)

- a lakás berendezése és jellemzői (a bútorzat jellemzői; függöny, szőnyeg, tapéta, csillár, dísztárgyak; reprezentatív vagy inkább otthonos?)

- térhasználat (kiknek van és kiknek nincs saját szobájuk?)

Szabadidő, szórakozás:

- a szórakozás/szabadidő eltöltésének nyilvános színterei (vurstli, mozi, színház, sportverseny, vendéglátóhely, parkok, kertek stb.)

- a szórakozás/szabadidő eltöltésének magán színterei (családi rendezvények, baráti összejövetelek, vendégeskedés formái, stb.)

- rendszeres vagy alkalmi, különleges esemény

- különböző társadalmi rétegek eltérő szórakozási/szabadidős szokásai

- a szabadidős/szórakozási tevékenység ideje (hétköznap, ünnepnap, esetleg nyaralás)

- különböző korosztályok és nemek eltérő szokásai (család együttes szabadidős tevékenységei, gyerekek, fiatalok, nők, férfiak speciális szokásai)

A harmadik forduló, vagyis a döntő, a diákok személyes részvételével Pécsett zajlik, melyre a legjobb nyolc csapat jut be. A programot két naposra terveztük, hogy a diákok ne csupán egy kiélezett versenyszereplésként éljék meg az egész tanéves készülésük csúcspontját, hanem oldottabb körülmények között bizonyíthassák képességeiket. A döntő péntek délután kezdődik az első két forduló legkiemelkedőbb alkotásaiból rendezett kiállítás megnyitójával. Az este folyamán az ország minden tájáról érkező csapatok - a verseny szelleméhez igazodva - szabadon választott müfajban, kreatív módon mutatkoznak be egymásnak és a szervezőknek, valamint a zsürinek. A döntőre szombat délelőtt kerül sor a Pécsi Tudományegyetemen. A zsüri tagjai között történelemtanárok és történészek ismét vegyesen foglalnak helyet. Az első feladat pörgős, bemelegítő jellegü, inkább az ismeretek felidézését igényli, pl. képfelismerés vagy topográfiai feladatok által. Ezután két összetettebb feladat következik, többnyire szituációs játékok, vagy vita, melyek során a diákoknak szövegeket kell alkotniuk és előadniuk úgy, hogy a megadott szerephez és a tárgyalt korhoz is hüek maradjanak. Az utolsó feladat történelmi kvíz, a Kérdezz-felelek! játék mintájára. (A kiállításmegnyitókról és a döntőkről készült videók megtekinthetők a verseny honlapján és facebook oldalán.)

Az eddigi tapasztalatok azt mutatják, hogy a diákok rendkívül nyitottak a kreatív feladatmegoldásra. Már a legelső meghirdetett Kreatív történelem tanulmányi versenyre több mint 100 csapat nevezett az ország minden pontjáról. A részt vevő, 
sőt a döntős csapatok tagjai közül sokan számoltak be arrról, hogy (a verseny elött) valójában nem is szerették a történelmet, pusztán a feladatok kreativitása miatt jelentkeztek - és nem bánták meg. Nemcsak gimnáziumok, de szakközépiskolák is rendszeresen részt vesznek eredményesen a versenyeken.

Az Árkádia és a Kreatív Történelem tanulmányi verseny a tudomány, a tanárképzés és a közoktatás kooperációjára épülnek: nemcsak az információ és a tudás kölcsönös átadását, sőt megvitatását, valamint egymás eredményeinek megismerését, adaptálását, de személyes kapcsolatok építését is elősegítik. A kezdeményezések létrehozói elsősorban a közoktatás igényeit tartották és tartják szem elött, de a közös tevékenység eredményei mindhárom terület számára egyaránt hasznosak és számos innovációt képesek elősegíteni. A Pécsi Tudományegyetem e két vállalkozása - szerencsére - nem egyedülálló jelenség, de mindenképpen fontos és iránymutató kezdeményezések, a történettudomány és a történelemtanítás közötti párbeszéd és együttmüködés egyre elismertebb fórumai.

\section{Irodalom}

Albert B. Gábor (2006): Súlypontok és hangsúlyeltolódások. Középiskolai történelemtankönyvek a Horthy-korszakban. Pannon Egyetem BTK Neveléstudományi Intézet, Pápa.

Bolla Márton (1847): Egyetemes világtörténetének föbb vonalai. Fordította Schröck Ferencz. $1-2$. kötet. Kilián, Pest.

F. Dárdai Ágnes - Kaposi József (2006): Merre tovább történelem érettségi? Javaslatok az új történelem érettségi továbbfejlesztésére. Új Pedagógiai Szemle, 9. sz. 21-35.

Gőzsy Zoltán - Dévényi Anna (2011): A történelem tanitásának tartalmi és módszertani változásai, Pécsi Tudományegyetem, Pécs. URL: http://janus.ttk.pte.hu/tamop/tananyagok/ tort tan_valt/index.html Letöltés ideje: 2015. 10. 10.

Mészáros István (1989): A tankönyvkiadás története Magyarországon. Tankönyvkiadó, Budapest-Dabas.

Romsics Ignác (2011): Clio büvöletében. Magyar történetírás a 19-20. században - nemzetközi kitekintéssel. Osiris, Budapest.

Szöke András (2004): Apostolok jogán? In: Albert B. Gábor (szerk.): Tudatformálás vagy tudattorzitás? Kölcsey Intézet, Budapest. 65-74. 